\title{
Perubahan Gaya Dakwah Da'i di Bulan Ramadhan \\ dalam Pandemi Covid 19 (Perspektif Psikologi Da'i)
}

\author{
Zidni Ilman Nafia \\ Universitas Negeri Islam Sunan Ampel Surabaya \\ zidniman03@gmail.com
}

Khafidoh

Institut Agama Islam Sunan Giri Ponorogo

khafidoh33@yahoo.com

\section{abstrac}

In the midst of the outbreak of the Covid 19 (Corona Virus) pandemic which has killed thousands of people in the world, it is a very frightening thing for most people, until the government implements regional closures, PSBB (large-scale social restrictions), and quarantine of such areas to stop the spread of this Corona Virus . However, in the middle of the holy month of Ramadan, preaching activities are increasingly being carried out because this month Muslims want to flock to improve themselves and increase their charity. Islam and da'wah are two inseparable things. Islam will not progress and develop bersyi'ar and shine without any efforts to preach. The more incessant preaching efforts are carried out, the more Islamic religion is shouting, the more lax the efforts of preaching the fainter the light of Islam in society. Latsaal-islam illa bi al-da'ah, that's a wise word expressed in the book of kyai prostitution. In facing the era of globalization of information and technological developments lately, the world is faced with the rapid development of information flows. It seems that the use of technology tools as a medium for conveying information to the public cannot be stopped. But on the contrary, the existence of sophisticated technology in the era of globalization of information and communication can be used for disseminating information and messages of Islamic da'wah. In relation to the psychology of da'i, da'i can do what he wants to do because of a change in social society. The psychology of a good da'i will be able to provide a good da'wah effect in society.

Keywords: da'wah, media, pandemic, psychology

\section{Abstrak}

Ditengah maraknya pandemi Covid 19 (Virus Corona) yang telah membunuh ribuan manusia di dunia, merupakan hal yang sangat menakutkan bagi kebanyakan orang, hingga pemerintah menerapkan penutupan daerah, PSBB (pembatasan soial 
berskala besar), dan karantina wilayah demikian untuk memutus penyebaran Virus Corona ini. Namun di tengah bulan suci Ramadhan kegiatan dakwah semakin gencar dilakukan karean di bulan ini umat muslim ingin berbondong-bondang memperbaiki diri dan memperbanyak amal. Islam dan dakwah adalah dua hal yang tak terpisahkan. Islam tidak akan maju dan berkembang bersyi'ar dan bersinar tanpa adanya upaya dakwah. Semakin gencar upaya dakwah dilaksanakan semakin bersyi' arlah agama islam, semakin kendor upaya dakwah semakin redup pula cahaya islam dalam masyarakat. Latsaal-islam illa bi al-daeewah, demikianlah sebuah kata bijak mengungkapkan dalam buku kyai prostitusi. Dalam menghadapi era globalisasi informasi dan perkembangan teknologi akhir-akhir ini, dunia dihadapkan pada cepatnya perkembangan arus informasi. Pemanfaatan alat-alat teknologi sebagai media penyampaian informasi kepada khalayak, sepertinya tidak dapat dibendung. Tetapi sebaliknya, keberadaan teknologi canggih di era globalisasi informasi dan komunikasi ini Dapat dimanfaatkan untuk penyebaran informasi dan pesan-pesan dakwah islam. Dalam kaitannya dengan psikologi da'i, da'i dapat melakukan apa yang dia ingin lakukan karena adanya suatu perubahan dalam sosial masyarakat. Psikologi da'i yang baik akan mampu memberikan efek dakwah yang baik di masyarakat.

Kata Kunci : dakwah, media, pandemi, psikologi

\section{Pendahuluan}

Pada umumnya di bulan Ramadhan umat muslim akan berlomba lomba mencari pahala sebanyak-banyaknya, karena adanya keutamaan bulan Ramadhan seperti dibukaanya pintu maghfiroh (maaf), pintu pahala yang di lipat gandakan sehingga tak sedikit orang muslim khusus nya di Indonesia banyak yang terlihat lebih sering ke masjid, membaca Al Qur'an, bersedekah dan kebutuhan mencari ilmu agama yang lebih di bulan suci Ramadhan.

Namun di kondisi saat ini berbeda dengan bulan suci Ramadhan sebelumnya di karenakan adanya pandemi covid 19. Sehingga pemerintah menghimbau kepada masyarakat untuk senantiasa di rumah saja, mengurangi aktivitas di luar rumah. Dengan tujuan untuk mencegah penyebaran covid 19.

Sehingga kondisi tersebut membuat para da'i tidak dapat memberikan kultum kajian ke islaman di masjid-masjid untuk mengajak umat muslim untuk senantiasa meningkatkan ibadah nya demi mendapatkan keutamaan bulan suci Ramadhan.

Untuk memenuhi kebutuhan umat muslim da'i harus mampu berinovasi dalam mengajak umat muslim untuk meningkatkan ibadahnya di bulan suci Ramadhan ini, meski dakwah menjadi tugas setiap umat muslim, seperti yang telah dijelaskan dalam Al-Qur'an dalam surat Ali Imron 
ayat 104 : Artinya: Dan hendaklah diantara di antara kamu ada segolongan orang yang menyeru kepada kebajikan, menyuruh (berbuat) yang makruf dan mencegah dari yang munkar. Dan mereka itulah orang-orang yang beruntung (Departemen Agama RI, 2010: 63).

Dengan demikian dakwah yang bersifat pembinaan adalah suatu usaha mempertahankan, melestarikan dan menyempurnakan ummat manusia agar mereka tetap beriman kepada Allah SWT, dengan menjalankan syari'at-Nya sehingga mereka menjadi manusia yang hidup bahagia di dunia maupun di akhirat (Asmuni, 1983:20).

\section{Kerangka Teori}

Penelitian seperti ini sebelumnya sudah pernah di lakukan oleh Agus salim dengan judul "Peran dan Fungsi Dai dalam Perspektif Psikologi Dakwah". Yng membahas mengenai Peran dan fungsi dai sebagai juru dakwah adalah salah satu faktor dalam kegiatan dakwah yang menempati posisi sangat penting dalam berhasil atau tidaknya kegiatan dakwah. Dai professional yang mengkhususkan diri di bidang dakwah, seyogianya memiliki kepribadian yang baik untuk menunjang keberhasilan dakwah baik yang bersifat rohani atau yang bersifat fisik. Hasil yang ingin diperoleh dengan pengetahuan tentang tulisan ini, diharapkan kita dapat melaksanakan tugas dakwah dengan pendekatan kejiwaan sehingga hal yang diharapkan peran dan fungsi seorang dai benar-benar dapat dipahami oleh seorang dai sebagai mubalig dan kondisi objek dakwah sebagai mad'u.

Sehingga oleh peneliti di jadikan sandaran dalam riset ini, riset ini bertujuan untuk melihat fenomena baru di dalam kegiatan dakwah yang oleh di lakukan oleh dai di bulan Ramadhan karena adanya pandemi covid 19. Bagaimana secara psikologis dai menghadapi tantangan baru ini, dan bagaimana dai mampu berinovasi untuk tetap dapat berdakwah.

\section{Metode Penelitian}

Metode penilitian ini menggunakan metode kualitatif diskriptif menggambarkan keadaan adanya perubaan gaya atau prilaku. Dengan objek pengamatan gaya dakwah dai dalam keadaan pandemi covid 19, artinya adalah penelitian ini dilakukan untuk mendapatkan data secara deskriptif mengenai fenomena sosial yang terjadi di tengah masyarakat (Moleong, 2000:3). Peneliti mengamati dai di desa Kamulan di pondok pesantren Darissulaimaniah dengan pendakwah gus Muhammad Nasir Lc. dengan apa yang di lakukan gus Nasir ketika di bulan ramadahan yang biasanya ngaji secara tatap muka namun dengan keadaan pandemi covid 19 ngaji tatap muka sangat lah membahayakan karena dapat berpotensi penyebaran covid 19.

Teknik pengumpulan data akan dilakukan secara wawancara, observasi, dan studi literayur, sehingga sumber data akan dapat di peroleh melalui hasil wawancara dengan pelaku dai, santri dan masyarakat yang menjadi mad'u, dan literatur yang berhubungan 
dengan topik pembahasan di dalam penelitian ini. Tahapan- tahapan dalam pengumpulan data dilakukan secara sistematis (Usman, 1996: 42).

\section{Dakwah Islam}

Hamzah Ya'qub mengatakan bahwa dakwah adalah mengajak umat manusia dengan hikmah (kebijaksanaan) untuk mengikuti petunjuk Allah dan Rasul-Nya.

Menurut Pro. Dr. Hamka dakwah adalah seruan panggilan untuk menganut suatu pendirian yang ada dasarnya berkonotasi positif dengan subtansi terletak pada aktivitas yang memerintahkan amar ma'ruf nahi mungkar (Wahidin, 2011:2).

Ditinjau dari segi etimologi atau asal kata (bahasa), dakwah berasal dari bahasa Arab, yang berarti "panggilan, ajakan atau seruan". Dalam Ilmu Tata Bahasa Arab, kata dakwah berbentuk sebagai “isim masdar". Kata ini bersal dari fi'il (kata kerja) "da'a-yad'u”, artinya memanggil, mengajak atau menyeru (Asmuni, 1983:17).

Menurut penulis dakwah merupakan ajakan secara lisan atau hanya tindakan pribadi yang baik sesuai dengan akhlak Rasulullah SAW, yang disampaikan dan dilihat oleh khalayak.

Kegiatan dakwah merupakan perintah Allah SWT kepada seluruh umat Islam, hukum dari berdakwah adalah wajib, perintah berdakwah tertera pada Al Quran dan juga Hadist.

Banyak ayat Al Quran maupun teks hadis Nabi SAW. Yang menguraikan tentang dakwah Islam. Di antara ayat -ayat dakwah yang menyatakan kewajiban dakwah secara tegas adalah surat an-Nahl ayat 125, surat Ali Imran ayat 104, dan surat al-Maidah ayat 78 dan 79.

Dalam surat al-Maidah ayat 78-79 tersebut Allah mengecam dengan keras Bani Israil yang meninggalkan dakwah. Mereka tidak memiliki kepedulian sama sekali kepada aktivis dakwah. Mereka "tidak melarang kemungkaran". Perintah ini juga tidak lebih tegas dibanding dengan ayat tersebut. Surat al-Maidah ayat 78-79 tersebut hanya menampilkan contoh nyata dari umat terdahulu yang disiksa karena mengabaikan perintah mencegah kemungkaran. Meskipun kecaman tidak ditunjukkan pada umat Nabi SAW, tetapi ia berlaku pada umat Nabi SAW, karena hukum umat terdahulu masih berlaku selama masih belum diganti (Ali Aziz, 2015 : 147)

Islam adalah agama dakwah, artinya agama yang selalu mendorong pemeluknya untuk senantiasa aktif melakukan kegiatan dakwah. Kemajuan dan kemunduran umat Islam sangat berkaitan erat dengan dakwah yang dilakukanya. Karena itu, Al Quran menyebut kegiatan dakwah dengan absanul qaula (ucapan) dan perbuatan baik.

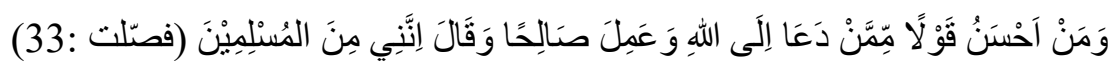


Siapakah yang lebih baik perkataanya dari pada orang yang menyeru kepada Allah, mengerjakan amal shaleh yang berkata: "sesungguhnya aku termasuk orang-orang yang menyerah diri?". (QS. al Fussilat, 41: 33).

Dakwah seperti yang diungkapkan dalam ayat tersebut tidak hanya dakwah berdimensi ucapan atau lisan tetapi juga dakwah dengan perbuatan yang baik (uswah) seperti yang telah dicontohkan oleh Rasulullah SAW (Munir, 2015:213). Dengan melakukan perbuatan-perbuatan baik yang di contohkan Rasulullah SAW kepada kita secara tidak langsung itu merupakan suatu kegiatan dakwah, dakwah yang hanya cukup menerapkan ilmu-ilmu agama pada diri sendiri dan diterapkan dalam prilaku keseharian dalam bermasyarakat.

Dewasa ini aktivitas dakwah Islam ini tidak cukup dengan menggunakan mediamedia tradisional, seperti melalui ceramah-ceramah dan pengajian-pengajian yang masih menggunakan media komunikasi oral atau komunikasi tutur. Penggunaan media-media komunikasi modern sesuai dengan taraf perkembangan daya pikir manusia harus dimanfaatkan sekedemikian rupa, agar dakwah Islam lebih mengena sasaran dan tidak out of date.

Media dakwah pada zaman Rasulullah dan sahabat sangat terbatas yakni berkisar pada dakwah qouliayyah bi al-lisan dan dakwah fi'liyyah al-uswah, ditambah dengan media penggunaan surat (rasail) yang sangat terbatas. Satu abad kemudian, dakwah menggunakan media, yaitu qashash (tukang cerita) dan muallafat (karangan tertulis) diperkenalkan. Media yang disebut terakhir ini berkembang cukup pesat dan dapat bertahan sampai saat ini (Samsul Munir, 2009 : 112).

Kata media, berasal dari bahasa latin, median, yang merupakan bentuk jamak dari medium secara etimologi yang berarti alat perantara.

Wilbur schramm mendefinisikan media sebagai teknologi informasi yang dapat digunakan dalam pengajaran.

Secara lebih spesifik, yang dimaksud dengan media adalah alat-alat fisik yang menjelaskan isi pesan atau pengajaran, seperti buku, film, video kaset, slide, dan sebagainya.

Adapun yang dimaksud dengan media dakwah, adalah peralatan yang dipergunakan untuk menyampaikan materi dakwah kepada penerima dakwah. Pada zaman modern seperti sekarang ini, seperti televisi, video, kaset rekaman, majalah, dan surat kabar. (Samsul Munir, 2009 : 113). 


\section{Dalam Tinjauan Psikologi Da'i}

Psikologi merupakan bagian dari ilmu yang tidak pernah habis untuk diperbincangkan, karena psikologi mengkaji aspek kejiwaan manusia. Akan tetapi beberapa dasawarsa istilah jiwa sudah jarang dipakai dan diganti dengan istilah psikis. Beberapa ahli mempelajari jiwa atau psikis manusia dari gejala-gejala yang diakibatkan oleh keberadaan psikis tersebut. Menurut pandangan Dimyati manusia menghayati kehidupan kejiwaan berupa kegiatan berfikir, berfantasi, sugesti, sedih dan senang, berkemauan dan sebaginya (Dimyanti:1994). Gejala jiwa pada manusia dibedakan menjadi gejala pengenalan (kognisi), gejala perasaan (afeksi), gejala kehendak (konasi), dan gejala campuran (psikomotorik). Gejala konasi merupakan suatu proses upaya manusia dalam mengenal berbagai macam stimulus atau informasi yang masuk ke dalam alat inderanya, menyimpan, menghubunghubungkan, menganalisis, dan memecahkan suatu masalah berdasarkan stimulus atau informasi tersebut. Termasuk dalam gejala pengenalan adalah penginderaan dan persepsi, asosiasi, memori, berfikir, inteligensi.

Dalam buku Psikologi Komunikasi oleh Jalaluddin Rakhmat, Raymond S. Ross (1974: 67) mendefinisikan komunikasi sebagai "a transactional process involving cognitive sorting, selecting, and sharing of symbol in such a way as to help another alicit from his own experiences a meaning or responses similar to that intended by the source." Proses transaksional yang meliputi pemisahan dan pemilihan bersama lambang secara kognitif, begitu rupa sehingga membantu orang lain untuk mengeluarkan dari pengalamannya sendiri arti atau respons yang sama dengan yang dimaksud sumber (Jalaluddin Rakhmat, 2013:3). Komunikasi sebagai proses transaksi pesan dari komunikator kepada komunikan baik berupa verbal maupun lambang untuk menciptakan pemahaman komunikan agar dapat respon serta adanya feedback dari komunikan maka terjalin komunikasi yang efektif.

Seorang komunikator untuk bisa dipercayai orang lain dalam orasinya baik pesanpesan yang disampaikan maupun tingkah lakunya yang baik sebagai contoh bagi masyarakat. Psikologi komunikator mengajak untuk menyadari bahwa ketika komunikator menyampaikan pesan kepada orang lain, yang berpengaruh bukan saja apa yang dikatakan tetapi juga keadaan kekinian yang sedang dialami. Pada teori psikologi komunikator terdapat komponen-komponen penting yaitu:

a. Ethos

Ethos merupakan sumber kepercayaan yang ditunjukkan kepada sang orator, bahwa ia memang pakar dalam bidangnya, maka ia dapat dipercaya, seorang komunikator yang handal, mau tidak mau harus melengkapi dirinya dengan dimensi ethos, karena ini yang 
memungkinkan orang lain menjadi percaya. Dimensi-dimensi ada tiga. Pertama, Kredibilitas (keahlian dan kepercayaan) adalah persepsi yang sederhana dapat diartikan pandangan pendengar terhadap komunikator akan tetapi persepsi tersebut tidak tetap melainkan berubah-ubah bergantung kepada pelaku persepsi, topik yang dibahas. Kedua, Atraksi adalah daya tarik komunikator yang bersumber dari fisik. Seorang komunikator disenangi dan dikagumi yang memungkinkan pandangan menerima kepuasaan dengan kata lain pendengar tunduk terhadap pesan yang dikomunikasikan komunikator. Ketiga, Kekuasaan adalah kemampuan menimbulkan ketundukan. Dimana ketundukan yang menimbulkan dari interaksi antara komunikator dan pendengar. Kepuasan menyebabkan seorang komunikator "memaksakan" kehendaknya kepada orang lain. karena ia memiliki sumber daya penting (Jalaluddin Rakhmat, 2013:4). Ethos bukanlah variabel tunggal melainkan ethos memiliki beberapa dimensi yaitu kredibilitas, atraksi dan kekuasaan. Satu sama lain bisa berdiri sendiri, tetapi bisa menjadi mungkin berkaitan dan menyatu. Artinya, seseorang memiliki ethos yang terdeskripsikan pada kredibilitas, atraksi dan kekuasaan.

b. Pathos

Pathos adalah kekuatan yang dimiliki oleh seorang tokoh dalam mengendalikan emosi khalayak (Anwar Arifin, 2011:240). Kriteria pathos ini ditunjukan oleh seorang rethor dengan menampilkan gaya dan bahasanya yang membangkitkan kegairahan dengan semangat yang berkobar-kobar kepada khalayak.

c. Loghos

Loghos adalah kekuatan yang dimiliki oleh seorang tokoh karena argumentasinya dalam berbicara kepada orang lain dan kepada orang banyak (khalayak) (Anwar Arifin, 2011:240). Kriteria loghos ini ditunjukkan oleh seorang bahwa uraian masuk akal sehingga patut diikuti dan dilaksanakan khalayak. Khalayak akan mau mengikuti ajakan komunikator dengan uraian yang masuk akal.

\section{A. PANDEMI COVID-19}

Virus dalam Kamus Besar Bahasa Indonesia Adalah mukroganisme yang tidak bisa dilihat dengan mikroskop biasa, hanya dapat dilihat oleh mikroskop elektron. Jelas bahwa Virus tidak bisa dilihat dari mata telanjang. Hal inilah yang menjadi sulit terdeteksi. Bahkan harus melewati beberapa proses pemeriksaan dan diagnosis yang dilakukan ahli tertentu. Dalam trend kali ini, virus yang menjadi pembahasan center di dunia adalah virus corona (Covid-19). 
Covid-19 disebabkan oleh virus korona (sefamili dengan penyebab SARS CoV-1 atau MERS (middle east respiratory syndrome), tetapi berbeda tipe. Namanya SARS CoV-2 (severe acute respiratory syndrome corona virus 2). Case fatality rate (CFR)-nya relatif lebih rendah daripada SARS CoV-1 dan MERS. Namun, spreading-nya jauh lebih mudah, masif, dan luas. Ada tiga kelompok yang terpapar korona.

Pertama, kelompok rentan/vulnerable. Kelompok ini jika terpapar sangat rentan untuk bermanifes klinis sedang sampai berat. Siapa kelompok ini? Orang tua/elderly (sistem imun dan fungsi organ sudah menurun), orang dengan penyakit penyerta (comorbid disease) terutama jantung, paru, diabetes, dan imunocompromized (sistem imun melemah). Kelompok ini harus dijaga betul supaya tidak terpapar.

Kedua, kelompok yang jika terpapar terjadi gejala ringan sampai sedang. Yang termasuk kelompok ini mungkin anak muda yang jarang berolahraga, kurang menjaga makan tetapi tanpa comorbid, dan termasuk anak-anak/remaja.

Ketiga, kelompok asimptomatis (OTG, orang tanpa gejala). Jika terpapar, daya tahan tubuh kelompok ini sangat kuat sehingga virus tidak bisa replikasi sehingga relatif tidak bergejala. Sayang, kelompok ini bisa menjadi carrier dalam arti sekalipun dia tidak bergejala, dia bisa menularkan ke orang lain.

Masalah wabah Corona/ Covid 19 menjadi musibah terbesar di seluruh dunia dimana wabah itu pertama kali muncul di wuhan China dan pada akhirnya meluas sampai seseluruh dunia karena Virus tersebut bisa di tularkan melalui manusia ke manusia lainnya. Dalam hal ini pentingnya sosialisasi dalam penanggulangan Covid 19 merupakan hal penting bagi setiap Negara agar tidak semakin banyak korban yang terjangkit wabah Virus mematikan tersebut. Tercatan hingga saat ini tanggal 28 Maret 2020 tercatat sudah ada 593.656 Kasus, 132.526 Sembuh dan 27.215 meninggal dalam hal ini tercatat saat ini Amerika Serikat menjadi Negara dengan kasus terbesar yaitu 102.396 kasus, 1.607 meminggal dan 2.471 sembuh.

Saat ini sudah menjadi pembahasan trending, bahwa ada virus baru yang sedang mengancam manusia yaitu Coronavirus Disease 2019 (Covid-19). Pertama kali terjadi pada bulan Desember di Wuhan, Tiongkok. Sebelum virus ini menyebar ke seluruh dunia atau ketika belum masuk ke Indonesia, Virus ini masih menjadi wabah. Penanganannya sebenarnya bisa dikendalikan, tetapi apa yang terjadi? Virus ini secara sigap menyerang siapa saja yang ada di depannya, tanpa pandang dari suku apa dan lahir di mana. Bahkan opini yang berseliweran mengatakan "Indonesia tidak akan terkena Covid-19 ini, dikarenakan iklim tropis di sini tidak mendukung tumbuhnya virus". Hal inilah yang 
mungkin menjadi spekulasi pemerintah dengan tidak secara sigap menyambut datangnya virus tersebut. Kata pepatah "sedia payung sebelum hujan" tak menjadi kerangka dalam mencegah virus yang tidak bisa terdeteksi kapan masuk dan keluar di Indonesia. Akhirnya, pada awal Februari, Ketika penularannya sudah terdeteksi, pemerintah secara resmi mengumumkan untuk pertama kalinya warga Indonesia terkena Covid-19. Tetapi hal itu belum juga menjadi dasar dalam pencegahan penularan virus, lama kelamaan korban pun bertambah dan akhirnya ada yang meninggal. Barulah pemerintah sadar dan membentuk badan khusus penanganan Covid-19.

\section{B. BULAN SUCI RAMDHAN}

Bulan Ramadhan adalah bulan yang ditunggu-tunggu oleh umat muslim di seluruh dunia, begitu pun di Indonesia. Meski saat ini dunia sedang berada dalam pandemi virus Corona Covid-19. Namun, hal tersebut diharapkan tidak akan mengubah nikmatnya menjalani ibadah puasa di bulan Ramadan, juga tidak akan mengurangi keutamaan bulan Ramadhan itu sendiri.

Selain melakukan beberapa upaya pencegahan terhadap penyebaran virus Corona dalam situasi ini, manusia juga diharapkan untuk banyak-banyak berdoa. Bulan Ramadan memiliki banyak keutamaan salah satunya adalah bulan pengampunan dosa.

Ceramah Ramadhan menjadi acara yang kerap mewarnai kegiatan bulan suci Ramadhan selain untuk melengkapi kegiatan zakat atau sedekah di sepanjang bulan suci ini. Ceramah tersebut biasa dilakukan dalam berbagai kesempatan, mulai dari waktu sebelum berbuka, setelah salat subuh, ataupun di tengah-tengah waktu istirahat salat tarawih.

Tema yang diusung dalam ceramah tersebut harus memiliki pengetahuan yang sesuai dengan situasi di bulan puasa. Dengan begitu, umat Islam dapat menjalankan ibadah puasa dengan sempurna. berikut ini 5 pilihan tema ceramah Ramadhan yang dapat dijadikan sebagai pertimbangan:

Ceramah Ramadhan Syarat Sah Puasa

ceramah puasa

Tema ceramah Ramadhan yang pertama bisa Anda pilih yang berkaitan dengan syarat sah puasa. Lewat tema ini, mereka yang mendengarkan ceramah bisa memperoleh pengetahuan mengenai rukun serta syarat wajib puasa bagi umat Islam. Di waktu yang sama, Anda juga dapat menyertakan keutamaan orang-orang yang berpuasa.

Selain itu, selipkan pula keutamaan yang dimiliki oleh Bulan Ramadhan dibandingkan dengan bulan-bulan lain. Pada bulan ini, Allah SWT memberikan anugerah 
berupa pahala yang berlipat ganda. Oleh karena itu, Bulan Ramadhan menjadi kesempatan berharga bagi umat Islam untuk memperbanyak amalan sebagai bekal menghadapi hari akhir.

Ceramah Ramadhan dapat Melenyapkan Penyakit Hati

manfaat mendengarkan ceramah

Hati yang bersih menjadi salah satu faktor yang dapat berpengaruh pada kesempurnaan ibadah puasa saat Ramadhan. Ada berbagai penyakit hati yang wajib diwaspadai oleh setiap muslim. Penyakit hati tersebut di antaranya adalah, kurangnya rasa iman, iri, dengki, sombong, tamak, resah, hasat, dan sebagainya.

Keberadaan penyakit-penyakit hati tersebut, berdampak sangat buruk dalam kehidupan sehari-hari. Tak heran kalau penyakit hati bisa membuat seseorang sulit bersosialisasi dengan orang lain.

Anda dapat menawarkan solusi mengatasi penyakit hati tersebut dengan memberikan pengetahuan berkaitan dengan hikmah puasa yang bisa menghilangkan penyakit hati. Hal ini hanya bisa didapatkan ketika puasa dilakukan secara ikhlas dan mengharapkan ridha Allah.

Ceramah Ramadhan Sedekah untuk Orang Berpuasa

ceramah tentang sedekah

Sedekah menjadi amalan yang harus selalu dilakukan oleh umat Islam. Memasuki Bulan Ramadhan, Anda harus mendorong umat Islam untuk meningkatkan aktivitas ini melalui khutbah. Apalagi, banyak keutamaan yang bisa didapatkan dari kegiatan bersedekah kepada orang berpuasa.

Sedekah kepada orang berpuasa di Bulan Ramadhan punya status lebih tinggi dibandingkan sedekah di bulan lain. Sedekah tersebut tidak hanya memunculkan pahala sedekah. Di waktu yang sama, orang yang bersedekah juga akan mendapatkan pahala layaknya orang berpuasa, tanpa mengurangi pahala puasa dari orang yang memperoleh sedekah.

Ceramah Ramadhan tentang Lailatul Qadar

ceramah lailatul qadar

Ceramah Ramadhan mengenai peristiwa lailatul qadar menjadi hal yang wajib disampaikan kepada setiap muslim. Lailatul qadar merupakan kesempatan emas bagi setiap muslim untuk mendapatkan pahala beribu kali lipat. Menjalankan ibadah saat lailatul qadar jauh lebih baik dibandingkan dengan ibadah di malam-malam biasa.

Ceramah Ramadhan tentang Zakat Fitrah 
ceramah zakat fitrah

Pada penghujung Bulan Ramadhan, semua orang Islam memiliki kewajiban untuk membayar zakat fitrah. Ceramah Ramadhan mengenai keutamaan zakat fitrah dapat menjadi pengingat serta motivasi umat Islam agar tak lupa menunaikan kewajiban tersebut. Apalagi, zakat fitrah tidak hanya menjadi kesempatan berbagi kepada orang yang membutuhkan, tetapi juga sebagai sarana penghapus dosa.

\section{PERUBAHAN GAYA DA'I}

Sebagaimana peranan da'i ditengah masyarakat tidak dapat dipisahkan bahwa dirinya adalah agent of change (agen pembaharu) yang berarti ia harus inovatif, dinamis serta kreatif. Ia harus selalu mencari ide-ide baru dan mengembangkannya sehingga terwujud suatu masyarakat yang lebih baik secara kepribadian ketimbang hari-hari sebelumnya.

Sifat-sifat seorang da'i antara lain dapat disebutkan sebagai berikut:

a. Harus beriman dan bertaqwa kepada Allah

b. Da'i harus ramah dan penuh pengertian

c. Da'i harus tawadhu atau rendah hati

d. Da'i harus sederhana dan jujur dalam tindakannya

e. Da'i harus tidak memiliki sifat egoisme

f. Da'i harus memiliki semangat yang tinggi dalam tugasnya

g. Da'i harus memiliki jiwa toleransi yang tinggi

h. Da'i tidak memiliki penyakit hati atau dengki. ( Asep, 2014:77)

Da'i merupakan orang yang menjalankan amanah Allah SWT, maka da'i harus memiliki sifat-sifat khusus, harus mempunyai kepribadian muslim sejati. Ada tiga sifat dasar yang harus dimiliki seorang da'i ke jalan Allah SWT yaitu:

a. Setia kepada kebenaran

b. Menegakkan perintah kebenaran

c. Menghadapi semua manusia dengan kebenaran (Hashmy, 2002:125).

Dilihat dari sudut pandang secara umum tujuan dakwah adalah terwujudnya kebahagiaan dan kesejahteraan hidup manusia di dunia dan di akhirat yang diridhai oleh Allah SWT. Tujuan dakwah secara umum yaitu: (Samsul Munir : 59).

Tujuan umum dakwah sesuatu yang hendak dicapai dalam dalam seluruh aktifitas dakwah. Ini berarti tujuan dakwah yang masih bersifat umum dan utama, dimana seluruh gerak langkahnya merupakan proses dakwah yang harus ditujukan dan diarahkan 
kepadanya, Tujuan utama dakwah adalah nilai-nilai atau hasil akhir yang ingin dicapai atau diperoleh oleh keseluruhan aktifitas dakwah.

Kebahagiaan di dunia maupun di akhirat adalah tujuan hidup manusia, serupa pula dengan tujuan dakwah. Sebab hidup bahagia di dunia dan di akhirat tidaklah semudah yang diucapkan dan yang diinginkan, tidak cukup dengan berdoa, tetapi perlu juga disertai dengan berbagai usaha. Berarti usaha dakwah baik dalam bentuk mengajak umat manusia agar bersedia menerima dan memeluk islam, maupun dalam bentuk amar ma'ruf dan nahi munkar, tujuannya adalah terwujudnya kebahagiaan dan kesejahteraan hidup di dunia dan di akhirat yang diridhai Allah SWT.

Da'i sebagai komunikator (sebutan dalam ilmu komunikasi) agar dapat berkomunikasi dengan komunikannya dengan efektif dan sesuai dengan apa yang diharapkan, maka da'i harus berpengetahuan dan memahami bidang psikologi, karena dengan memahami pengetahuan ini da'i akan bersikap bijaksana dan pantang putus asa dalam menghadapi komunikannya yang sikap dan kepribadiannya beraneka ragam.

Selama ini apa yang dimaksud psikologi dakwah adalah perbekalan bagi calon seorang da'i dalam memahami psikologi masyarakat agar masyarakat dengan berbagai perkembangan psikologisnya dapat memahami apa yang disampaikan oleh da'i, dan sebaliknya, seorang da'i dapat mengendalikan emosinya pada saat berdakwah di tengahtengah masyarakat mad'u.

Kita sering menemukan dalam sejarah pemikiran manusia mengenai seluruh kenyataan itu adalah materi, kita juga dapat membaca hasil-hasil penelitian ilmuan yang mengasumsikan kesatuan ilmu, atau setidak-tidaknya semua ilmu itu dapat dibaca melalui natural sain, yang demikian itu secara sadar atau tidak sadar, maka alur pemikiran mereka menganggap bahwa kenyataan yang diteliti itu bersifat materi. Tetapi juga ada dalam sejarah pemikiran manusia itu yang membela bahwa seluruh kenyataan itu bersifat ruhani. Kedua pemikiran itu sama-sama bertentangan dengan pengalaman manusia yang normal. Kenyataan itu ternyata lebih kompleks dari hanya sekedar dua kutub yang berseberangan itu. Oleh karenanya juga ada para pemikir yang berusaha mempertahankan kedua unsur itu dalam satu kesatuan. Dan yang menganggap bahwa segi ruhani lebih tinggi dibanding segi jasmani.

Dengan demikian para ilmuwan dakwah justru harus memberikan jawaban secara khusus, mengenai pertanyaan apakah kenyataan dakwah itu bersifat ruhani atau jasmani? Apakah dakwah itu roh atau materi? 
Kemajuan ilmu pengetahuan dan teknologi membawa perubahan yang sangat besar dalam berbagai segi tatanan kehidupan manusia, mulai dari cara berpikir, bersikap, dan bertingkah laku. Tetapi dalam dimensi lain kemajuan ilmu pengetahuan dan teknologi telah menimbulkan dampak yang dapat mengancam kehidupan manusia (M. Jakfar, 2006:131). Modernisasi dan globalisasi di satu sisi membawa banyak manfaat bagi kehidupan manusia, tetapi disisi lain, bagi masyarakat yang secara psikologis belum siap menghadapi perubahan, modernisasi dapat menciptakan kesulitan psikologis (Mubarok, 2008:47), seperti ditegaskan Faridl, (Miftah Faridl, 2005:71) “napas kehidupan di tengah-tengah arus modernism diwarnai dengan berbagai kegelisahan moral, sosial, maupun spiritual”.

Kemajuan dan perkembangan kehidupan yang dihasilkan manusia di bidang ilmu pengetahuan, teknologi informasi dan komunikasi di zaman modern sekarang ini, secara positif membantu dan memberikan kemudahan bagi manusia, seperti mudahnya mengakses dan menyampaikan informasi, lancarnya transportasi dan komunikasi, cepatnya melakukan berbagai aktivitas perekonomian, dan lain sebagainya. Namun demikan, tidak dapat dipungkiri bahwa cepatnya arus perubahan yang terjadi, juga membawa dampak negatif yang melahirkan berbagai persoalan dalam kehidupan, salah satu diantaranya adalah merosotnya nilai-nilai moralitas manusia.

Di era modern ini manusia mengalami krisis nilai-nilai insani, karena manusia tidak sanggup mengantisipasi kemajuan ilmu pengetahuan dan teknologi yang menyebabkan timbulnya perubahan-perubahan sosial dan sosial keagamaan, termasuk perubahan tradisional kepada modern. Bangsa Indonesia saat ini tengah terpuruk dalam krisis multi dimensional, krisis kepercayaan (amanah), krisis moral, ekonomi, sosial politik dan budaya. Oleh karena itu membangun aktivitas dakwah yang sanggup menghadapi tantangan merupakan suatu keharusan yang tidak boleh ditunda-tunda (Nana Rukmana, 2002: 169).

Kecenderungan pola pikir masyarakat modern saat ini, juga banyak dipengaruhi oleh gaya hidup dan pemikiran sekularisme yang mengakibatkan pergeseran pemahaman dan cara pandang manusia, dari yang bersifat kolektif ke individualistik, dari yang bernuansa agamis ke materialistik. Kecenderungan ini tentu saja mempengaruhi pola hidup keagamaan masyarakat modern (Samsul Munir, 2008:35)

Kajian untuk memahami aspek mental dan proses perilaku manusia terkait dengan proses dakwah, dalam sistem dakwah disebut psikologi dakwah, yaitu sebuah kajian yang membahas tentang aspek mental dan perilaku manusia dalam proses dakwah, khususnya terkait dengan psikologi da'i, psikologi mad'u dan psikologi maudhu (Enjang, 2008: 258). 
Psikologi dakwah adalah ilmu bantu yang sangat diperlukan dalam menyampaikan pesan kebenaran kepada masyarakat. Manusia adalah makhluk yang memiliki keunikan psikologis, sehingga persepsi manusia bisa berbeda-beda terhadap objek yang sama. Keberhasilan suatu dakwah tidak hanya ditentukan oleh nilai pesan yang disampaikan, tetapi juga ditentukan oleh bagaimana persepsi masyarakat mad'u terhadap pesan dakwah itu. Psikologi dakwah antara lain berusaha menguak suasana batin dari manusia yang menjadi objek dakwah sehingga dengan itu dakwah bisa secara persuasif. Dakwah persuasif adalah proses mengajak atau mempengaruhi mad'u mengikuti ajaran da'i, tetapi ia merasa sedang melakukan sesuatu atas kehendak sendiri (Malik Fajar, 2008:5).

Pada hakikatnya psikologi dakwah sebagai ilmu pengetahuan bertugas mempelajari/membahas tentang gejala-gejala hidup kejiwaan, baik dari da'i maupun mad'u yang terlibat dalam proses kegiatan dakwah. Dengan memperhatikan faktor-faktor perkembangan psikologis beserta ciri-cirinya, maka pesan dakwah yang disampaikan oleh juru dakwah akan dapat meresap dan diterima dalam pribadi sasarannya dan kemudian diamalkannya kepada perasaan yang tulus tanpa adanya ganjalan karena hal tersebut dapat menyentuh dan memuaskan kehidupan rohaninya. Disinilah letak titik berat strategi-strategi dakwah yang sebenarnya yaitu menerima pesan dakwah dengan ikhlas sekaligus mempraktikkannya.

Tujuan psikologi dakwah adalah membantu dan memberikan pendangan kepada para da'i tentang pola dan tingkah laku para mad'u dan hal-hal yang mempengaruhi tingkah laku tersebut yang berkaitan dengan aspek kejiwaan (psikis) sehingga mempermudah para da'i untuk mengajak mereka kepada apa yang dikehendaki dalam ajaran Islam. Enjang dan Aliyudin (Enjang, 2009:151), mengatakan bahwa kajian psikologi dakwah bertujuan memberikan pandangan tentang aspek: "Psikologi da'i, yang menjadi subjek atau pelaku dakwah.

Kajian psikologi da'i berkaitan dengan aspek kognitif, afektif dan psikomotorik, serta kepribadian da'i. Psikologi pesan, kajiannnya terkait mengendalikan pemahaman, perasaan, serta dimungkinkannya dilakukan perubahan sikap mental dan perilaku sasaran dakwah (mad'u) sesuai dengan pola kehidupan yang dikehendaki oleh ajaran agama.

Berkaitanya dengan pandemi Covid 19, karenanya membuat orang satu dengan yang lain harus jaga jarak (social distancing), kegiatan keagamaan, ceramah di tiadakan sementara guna mencegah penularan virus ini, seperti kegiatan rutin sholat 5 waktu berjamaah dimasjid, sholat jum'at menjadi di batasi hingga ditiadakan di tempat-tempat tertentu yang daerahnya sudah terpapar berat. 
Karena hal itu agar tidak menghilangkan kegiatan dakwah dalam bulan suci Ramadhan seorang da'i menjadi memaksimal media Online untuk mensyiarkan agama. Media yang digunakan kebanyakan adalah youtube, dengan media ini da'i bisa melakukan syiarnya secara langsung dan tak terbatas kepada siapa mad'unya yang dituju. model dakwah seperti ini sebenarnya sudah banyak dilakukan oleh kyai dan ustadz, namun karena adanya pandemi ini menjadi lebih banyak lagi kyai dan ustadz melakukan ceramahnya di media.

\section{KESIMPULAN}

Syaikh Ali Makhfudz, dakwah Islam yaitu; mendorong manusia agar berbuat kebaikan dan mengikuti petunjuk (hidayah), menyeru mereka berbuat kebaikan dan mencegah dari kemungkaran, agar mereka mendapatkan kebahagiaan di dunia dan akhirat. Sebagaimana peranan da'i ditengah masyarakat tidak dapat dipisahkan bahwa dirinya adalah agent of change (agen pembaharu) yang berarti ia harus inovatif, dinamis serta kreatif.

Bulan Ramadhan umat muslim akan berlomba lomba mencari pahala sebanyakbanyaknya, karena adanya keutamaan bulan Ramadhan seperti dibukaanya pintu maghfiroh (maaf), pintu pahala yang di lipat gandakan sehingga tak sedikit orang muslim khusus nya di Indonesia banyak yang terlihat lebih sering ke masjid, membaca Al Qur'an, bersedekah dan kebutuhan mencari ilmu agama yang lebih di bulan suci Ramadhan.

Masalah wabah Corona/ Covid 19 menjadi musibah terbesar di seluruh dunia dimana wabah itu pertama kali muncul di wuhan China dan pada akhirnya meluas sampai seseluruh dunia karena Virus tersebut bisa di tularkan melalui manusia ke manusia lainnya. Dalam hal ini pentingnya sosialisasi dalam penanggulangan Covid 19 merupakan hal penting bagi setiap Negara agar tidak semakin banyak korban yang terjangkit wabah Virus mematikan tersebut.

Kajian psikologi da'i berkaitan dengan aspek kognitif, afektif dan psikomotorik, serta kepribadian da'i. Psikologi pesan, kajiannnya terkait mengendalikan pemahaman, perasaan, serta dimungkinkannya dilakukan perubahan sikap mental dan perilaku sasaran dakwah (mad'u) sesuai dengan pola kehidupan yang dikehendaki oleh ajaran agama. Dengan mengetahui ilmu psikologi dai harapanya da'i sebagai komunikator dapat berkomunikasi dengan komunikannya dengan efektif dan sesuai dengan apa yang diharapkan. 


\section{REFERENSI}

AS Enjang., "Smart Dakwah: Proses Dakwah Sesuai dengan Aspek Psikologi Mad'u”, (dalam Jurnal Ilmu Dakwah: Academic Journal for Homiletic Studies. Fakultas Dakwah UIN Sunan Gunung Djati Bandung, Vol. 4 No. 12/Juni-Desember 2008)

Arifin Anwar, 2011, Dakwah Kontemporer, Sebuah Studi Komunikasi, Yogyakarta: Graha Ilmu Amin Samsul Munir, 2008, "Rekontruksi Pemikiran Dakwah Islam", Jakarta: Amzah

Amin Samsul Munir, 2009, Ilmu Dakwah, Jakarta: AMZAH

Aziz Moh. Ali, 2015 , Edisi Revisi Ilmu Dakwah, Jakarta: Kencana

Dimyanti, 1994, Belajar dan Pembelajaran, Jakarta: Depdikbud

EM Sutisna, Skenario Akhir Pandemi Covid-19, opini ini dipubikasikan oleh Jawapos pada tanggal 24 April 2020.

Enjang dan Aliyudin, 2009, “Dasar-dasar Ilmu Dakwah”, Bandung: Widya Padjadjaran

Fajar A. Malik dalam Ahmad Mubarok, 2008, "Psikologi Dakwah", Cetakan keempat, Jakarta: Pustaka Firdaus

Faridl Miftah, 2005, “Cahaya Ukhuwah”, Bandung: Ikhtiar Publishing

Hashmy, 2002, Dustur Dakwah Menurut Al-Qur'an, (Jakarta: PT bulan Bintang,), h. 125

http://makalah-ibnu.blogspot.com/2008/10/peran-psikologi-dalam-proses-dakwah.html [04/05/2020].

http://ishthesyndicate.blogspot.com/2013/06/psikologi-dakwah-antar-budaya.html [04/5/2020].

https:// Kompas.com. di akses pada 8 Mei 2020

KBBI V iOS 1.4 (15), Badan Pengembangan dan Pembinaan Bahasa, Kemendikbud RI, 2018

Mubarok Ahmad, 2008, “Psikologi Dakwah”, Cetakan keempat, Jakarta: Pustaka Firdaus

Muhyiddin Asep, Dindin Solarahudin, 2014, Kajian Dakwah Multiperspektif, Bandung: PT Remaja Rosdakarya

Munir M., 2015, Metode Dakwah, Jakarta: Kencana

Mustakim, Gerak Cepat Lawan Corona, dipublikasin oleh Kompas dalam Edisi Kolom Opini tanggal 8 Mei 2020.

Puteh M. Jakfar, 2006, "Dakwah di Era Globalisasi: Strategi Menghadapi Perubahan Sosial”, Cetakan Ketiga, Yogyakarta: Ak. Group 
QS. al Fussilat (41): 33.

Rakhmat Jalaluddin, 2013, Psikologi Komunikasi, Bandung: PT. Remaja Rosdakarya

RI Dapartemen Agama, 2010, Al-Qur'an dan Terjemahnya Bandung: CV Penerbit Diponegoro,

Rukmana Nana D.W. 2002, "Masjid dan Dakwah: Merencanakan, Membangun dan Mengelola Masjid Mengemas Sbstansi Dakwah Upaya Pemecahan Krisis Moral dan Spiritual", Jakarta: Almawardi Prima

Syukir Asmuni, 1983, Dasar-Dasar Strategi Dakwah (Surabaya: Al-Ikhlas,

Saputra Wahidin, 2011, Pengantar Ilmu Dakwah, Jakarta: PT Raja Gafindo Persada 